\title{
Comparison of brazed joints made with BNi-1 and BNi-7 nickel-base brazing alloys $(\cdot)$
}

\author{
Borut Zorc" and L. Kosec"
}

\begin{abstract}
Nickel-base brazing alloys are produced on the basis of three binary alloy systems, i.e. $\mathrm{Ni}-\mathrm{P}, \mathrm{Ni}-\mathrm{Si}$, and $\mathrm{Ni}-\mathrm{B}$. In metallurgical reactions with the parent metal the brittle eutectic in the brazing gap may transform into a ductile solid solution with all brazing alloys. Kinetics of the processes are different with different types of brazing alloys. Precipitation processes in the parent metal close to the brazing gap are of great importance. They control the mechanical properties of the joint area when the brittle eutectic has disappeared from the gap. A comparative study of brazed joints on austenitic stainless alloys made with $\mathrm{BNi}-7$ (Ni-P type) and $\mathrm{BNi}-1$ (Ni-Si-B type) brazing alloys was made. Brazing alloys containing phosphorus behave in a different manner to those containing boron.
\end{abstract}

Keywords Brazed joint. Diffusion annealing. Metallurgical reactions. Microstructure. Mechanical properties.

\section{Comparación de uniones soldades hechas con aleaciones de níquel BNI-1 y BNI-7}

Resumen Las aleaciones de níquel se producen mediante tres sistemas de aleación: $\mathrm{Ni}-\mathrm{P}, \mathrm{Ni}-\mathrm{Si}$ y $\mathrm{Ni}$-B. Durante las reaciones metalúrgicas con el metal de base, la eutéctica frágil en la separación soldada puede transformarse en la solución dúctil-sólida con todas aleaciones. La cinética del proceso varía según el tipo de aleación. Los procesos de precipitación en el metal de base cerca de la separación soldada son de mucha importancia, ya que controlan las propiedades mecánicas de la área de unión después de desaparecer la eutéctica frágil de la separación. Se ha hecho un análisis comparativo de uniones soldadas en aleaciones austeníticas inoxidables realizadas con aleaciones $\mathrm{BNi}$-7 (tipo $\mathrm{Ni}-\mathrm{P}$ ) y $\mathrm{BNi}$-1 (tipo $\mathrm{Ni}-\mathrm{Si}-\mathrm{B}$ ). Las aleaciones que contienen fósforo se comportan de una manera diferente, tanto con el cambio de la eutéctica a la solución sólida, como con los procesos de precipitación en el metal de base cerca de la unión soldada.

Palabras clave Unión soldada. Recocido de difusión. Reacciones metalúrgicas. Microestructura. Propiedades mecánicas.

\section{INTRODUCTION}

Nickel-base brazing alloys are used because of their good corrosion resistance and other properties, from extremely low temperatures up to very high temperatures ${ }^{[1]}$. They are commonly used for brazing stainless steels and nickel alloys. For lowering the melting point, brazing alloys contain phosphorus, boron or silicon while other elements provide high oxidation resistance $(\mathrm{Cr})$ and hightemperature resistance (W).

Nickel-base brazing alloys are very brittle due to eutectics and intermetallic phases. A brazing alloy microstructure in the brazing gap may be transformed in a ductile solid solution by a controlled brazing process or isothermal diffusion annealing. The process kinetics are much slower with the brazing alloys containing phosphorus than with the brazing alloys containing silicon and boron $^{[2,3]}$. The brazing alloys containing phosphorus are considered the most brittle of $\mathrm{all}^{[4-6]}$. This seems to be a reason that in various studies the brazing alloys containing boron and silicon are given preference.

In studies of microstructure changes and determination of maximum gap width in brazed

(•) Trabajo recibido el día 14 de diciembre de 1999 y aceptado en su forma final el 14 de abril de 2000

$\left(^{*}\right) \quad$ Welding Institute, Ptujska 19, 1000 Ljubljana (Slovenia).

$\left({ }^{* *}\right)$ University of Ljubljana. Faculty of Natural and Technical Sciences. Aškerceva c. 12, 1000 Ljubljana (Slovenia). 
joints to achieve the solid solution as a function of brazing parameters i.e. temperature/time/gap diagrams $^{[2,7]}$, Lugscheider used a brazing alloy containing phosphorus, i.e. $\mathrm{BNi}-7^{[2]}$. He found that the applied conditions of diffusion annealing of brazing joints did not affect $\mathrm{BNi}-7$ brazing alloy. In contrast the microstructure and the mechanical properties of brazed joints containing boron $(\mathrm{BNi}$ 2) and silicon (BNi-5) improved considerably. Similar results where found when brazing wide-gap joints $^{[3]}$.

In nuclear engineering, brazing alloys containing boron are not used due to a very large neutron absorption cross-section, which reduces the reactor performance. Additionally boron will transmute to helium due to radiation, which produces porosity, risk of material swelling and, consequently, brittleness of the materials ${ }^{[5,8]}$. For this application only nickel-base brazing alloy containing phosphorus and silicon should be considered. The brazing alloys containing silicon are superior to the ones containing phosphorus. Because of their lower melting point, however, the brazing alloys containing phosphorus have become established as well ${ }^{[5,8]}$. Brazing alloys of the siliconphosphorus type have also been produced ${ }^{[5,8 \text { and } 9]}$. In this case, phosphorus lowered the melting point of the silicon-type brazing alloy.

It was found that the brazing alloys containing phosphorus show very good wettability and may give a ductile solid solution in the joint in the case of a very narrow gap, and controlled and very thin deposited brazing alloy layers, e.g. by electroless $\mathrm{Ni}-\mathrm{P}$ plating ${ }^{[5]}$. Electroless Ni-P layers are mostly used as corrosion resistant and hard deposits on steels. These deposits may be subsequently remelted, e.g. by laser ${ }^{[11]}$.

The paper of this investigation is to conduct metallurgical characterisation of $\mathrm{BNi}-1$ (silicon- boron type) and $\mathrm{BNi}-7$ (phosphorus type) nickelbase brazing alloys in brazing of thin plates of three different austenitic stainless alloys, including some of mechanical tests. It was found that the brazing alloy containing phosphorus -in spite of a low rate of transformation of the brittle eutectic into the solid solution- showed a certain advantage over the one containing boron.

\section{EXPERIMENTAL PROCEDURE}

Chemical composition of the materials used is given in table I in which the materials are designated in accordance with SAE/AWS Unified Numbering System and other more common designations.

\subsection{Joint brazing}

Lap and butt joints were brazed using argon as a shielding atmosphere. Brazing of test pieces was performed in a laboratory quartz tube furnace. Argon was additionally blown into it from one side. The temperature was controlled by a $\mathrm{Ni}-\mathrm{NiCr}$ thermocouple, which was located below the joint location in the test piece.

Brazing conditions:

- shielding atmosphere: argon,

- brazing temperatures: $1,000,1,050,1,100,1,150$ ${ }^{\circ} \mathrm{C}$; in the course of brazing the temperature varied by $\pm 10^{\circ} \mathrm{C}$,

- brazing times: $5 \mathrm{~min}, 10 \mathrm{~min}$,

- dew point was not measured.

\subsection{Diffusion annealing of brazed joints}

Subsequent annealing of the lap and butt brazed joints (brazed $10 \mathrm{~min}$ at $1,100^{\circ} \mathrm{C}$ ) was carried out

Tabla I. Chemical composition and thickness of the materials used (wt.-\%)

Table I. Composición química y grosor de los materiales utilizados (\% en peso)

\begin{tabular}{|c|c|c|c|c|c|c|c|c|c|c|c|c|c|c|}
\hline Alloy (UNS) & Other designation & $\mathrm{Ni}$ & $\mathrm{Cr}$ & $\mathrm{Mn}$ & $\mathrm{Fe}$ & $\mathrm{Si}$ & Al & $\mathrm{Ti}$ & $\mathrm{Cu}$ & B & C & $P$ & $S$ & $\mathrm{t}(\mathrm{mm})$ \\
\hline N08800 & INCOLOY 800 & 32.5 & 21.0 & 0.75 & 46.0 & 0.5 & 0.38 & 0.2 & 0.38 & - & 0.05 & - & 0.008 & $0.6,0.7$ \\
\hline S32100 & AISI 321 & 10.0 & 18.0 & 2.0 & 68.8 & 1.0 & - & $>5 x \% C$ & - & - & $<0.1$ & - & $<0.025$ & 0.7 \\
\hline S30400 & AISI 304 & 9.5 & 18.0 & 2.0 & 69.5 & 1.0 & - & - & - & - & $<0.08$ & - & $<0.025$ & 1.0 \\
\hline N99710 & AWS BNi-7 & 77 & 13 & - & - & - & - & - & - & - & $<0.1$ & 10 & - & paste \\
\hline N99600 & AWS BNi-1 & 74 & 14 & - & 4.5 & 4.5 & - & - & - & 3 & 0.8 & - & - & paste \\
\hline
\end{tabular}


in the furnace with a quartz tube in an argon atmosphere. Annealing was carried out in two steps because after the first annealing step the results obtained were not satisfactory. The annealing conditions were as follows:
b) step 1: $T=1,050 \pm 10^{\circ} \mathrm{C}, t=2 \mathrm{~h}$
c) step 2: T=1,100 $\pm 10^{\circ} \mathrm{C}, t=6 \mathrm{~h}$

The joints were metallographically examined by means of optical microscopy, neutron-induced autoradiography, and electron microprobe analysis. The joints were also subjected to bend testing (mandrel diameter $=1.0 \mathrm{~mm}$, distance between supports $=3.5 \mathrm{~mm}$ ). In bend testing, the overlap joints peeled off and the butt joints bent. The test specimens used were $10 \mathrm{~mm}$ wide and $80 \mathrm{~mm}$ long.

\section{RESULTS AND DISCUSSION}

\subsection{Brazed joints}

Brazed joints on INCOLOY 800 are shown in figure 1 . With both brazing alloys the solid solution formed on the parent metal in the gap, and grew towards the gap centre. With BNi-1 brazing alloy the crystal grains of the solid solution were more numerous than with $\mathrm{BNi}-7$ brazing alloy and formed a continuous band. A larger volume of the solid solution obtained with $\mathrm{BNi}-1$ brazing alloy is attributed to a faster diffusion of boron in comparison to phosphorus. Boron was interstitially dissolved in austenite ${ }^{[10]}$ and phosphorus, due to its large atoms, in a substitutional manner, which affected the difference in rate of diffusion of the two elements.

Formation of the solid solution from the liquid brazing alloy may be explained by means of a hypothetical case of brazing $X$ metal with the $(\mathrm{X}+\mathrm{Y})$ eutectic alloy having a composition $(\mathrm{A})$ at a brazing temperature $T_{s}$ (Fig. 2). Between the liquid brazing alloy having the composition (A) and $\mathrm{X}$ metal there is not equilibrium possible. The joint is made of two parts of the solid X metal. Between the two we find the molten eutectic having the composition (A). At both sides of the filled-in gap a narrow, solid intermediate layer having a composition (C) will form due to dissolution of $\mathrm{X}$ metal in the brazing alloy and of $\mathrm{Y}$ metal in the solid $\mathrm{X}$ metal. Consequently, the concentration of $Y$ metal in the liquid reduces from (A) to (B). Thus the solid solution in the gap increases in volume at the expense of the eutectic.

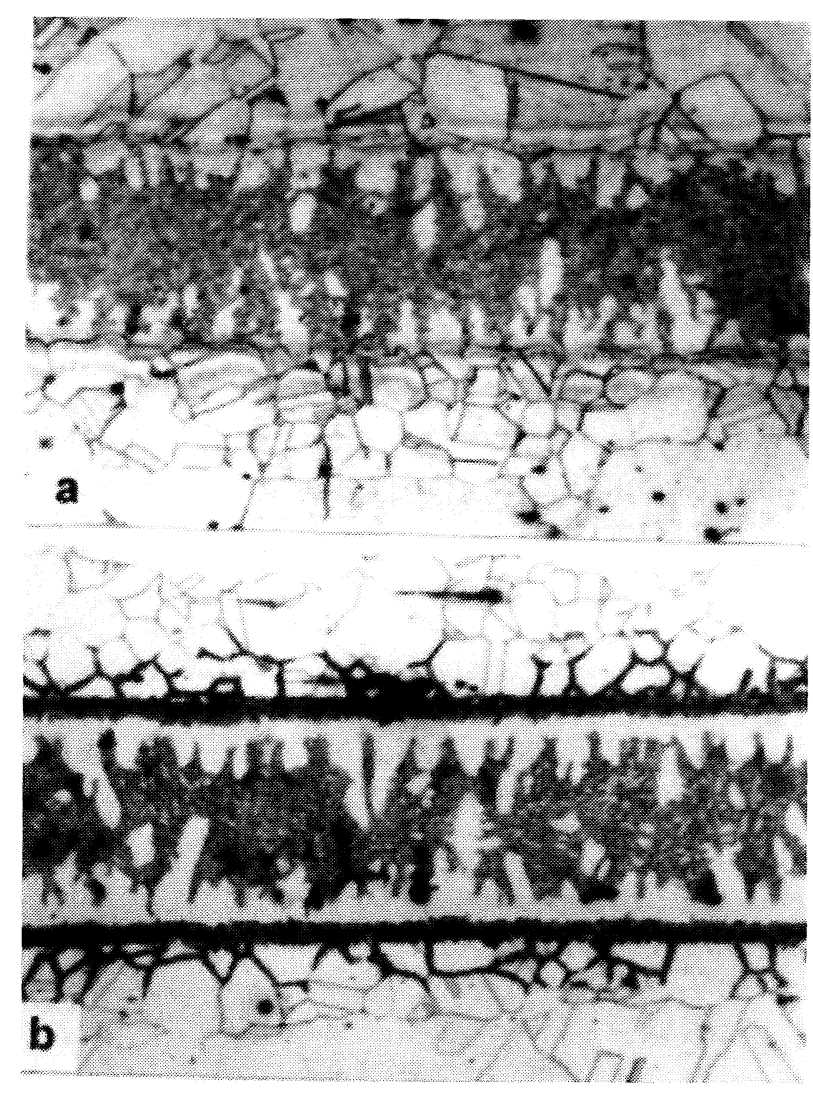

Figura 1. Microstructure of brazed joints on INCOLOY 800. (a) $\mathrm{BNi}-7$ brazing alloy. (b) $\mathrm{BNi}-1$ brazing alloy. Brazing parameters: $T=1,050^{\circ} \mathrm{C}, t=10 \mathrm{~min}$; 130x.

Figure 1. Microestructura de uniones soldadas en aleación INCOLOY 800. (a) aleación BNi-7. (b) aleación BNi-1. Parámetros de soldeo: $\mathrm{T}=1.050^{\circ} \mathrm{C}, \mathrm{t}=10 \mathrm{~min} ; \times 130$

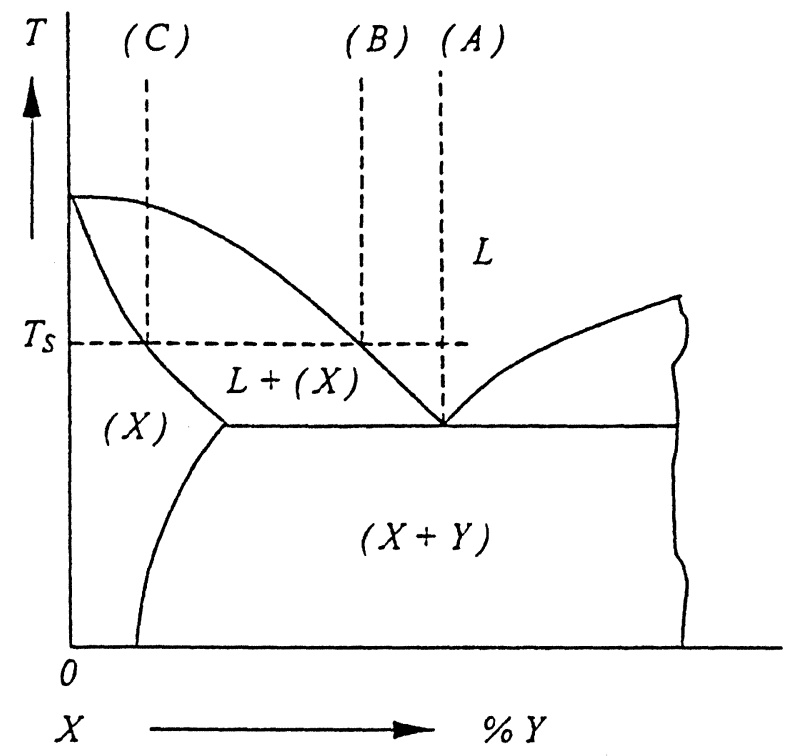

Figura 2. Sequences of solid solution formed by brazing solid metal with liquid eutectic alloy.

Figure 2. Formación de la solución sólida soldando el metal sólido con la aleación de la eutéctica líquida.

Rev. Metal. Madrid 36 (2000) 
After a certain brazing time at the brazing temperature $T_{s}$ (diffusion heat treatment) the eutectic will disappear from the gap and the gap will be completely filled with the solid solution. The latter will make a strong and tough bond between the two parts.

In the parent metal close to the gap, transcrystalline and intercrystalline precipitates were found with $\mathrm{BNi}-1$ brazing alloy. The intercrystalline precipitates were found deeper in the parent metal due to more rapid grain boundary diffusion. The neutron-induced autoradiography and the electron microprobe analysis showed complex $(\mathrm{Cr}, \mathrm{Fe}, \mathrm{Ni})$ borides. Silicon may be found in some precipitates, but generally it was found in the solid solution. Because of rapid boron diffusion into the parent metal and its low solubility in austenite, the parent metal close to the gap was quickly oversaturated with boron. This produced a strong precipitation of borides having a very dense arrangement, which produced a strong hardening of the parent austenitic matrix and increased brittleness of the area.

Because of low phosphorus diffusion into the parent metal with $\mathrm{BNi}-7$ brazing alloy, there were no precipitates. Brazing parameters did not suffice for supersaturation of the parent metal in phosphorus irrespective of the chemical composition of the parent metal.

Both brazing alloys are brittle. In the bend test the butt joints fractured without deformation of the test pieces. A crack propagated in the eutectic, in the bend (peel) mainly along the line close to the newly formed solid solution (Fig. 3). The eutectic mixtureis the weakest part of the brazed joint. Irrespective of the brazing parameters, the type of brazing alloy and the parent metal, properties of all the joints were similar and very unsatisfactory.

\subsection{Diffusion-annealed brazed joints}

Figure 4 shows diffusion-annealed joints. With $\mathrm{BNi}-7$ brazing alloy, areas of eutectic in the joint were still found while with $\mathrm{BNi}-1$ brazing alloy only the solid solution was found.

With $\mathrm{BNi}-1$ brazing alloy, there were densely arranged borides in the parent metal in the case of wider brazing gaps while there were none in the narrow gaps (Figs. $4 \mathrm{c}$ and d). Since in the narrow gap there was less brazing alloy (and consequently boron), the borides, with the parameters used, dissolved and boron passed into the solid solution.

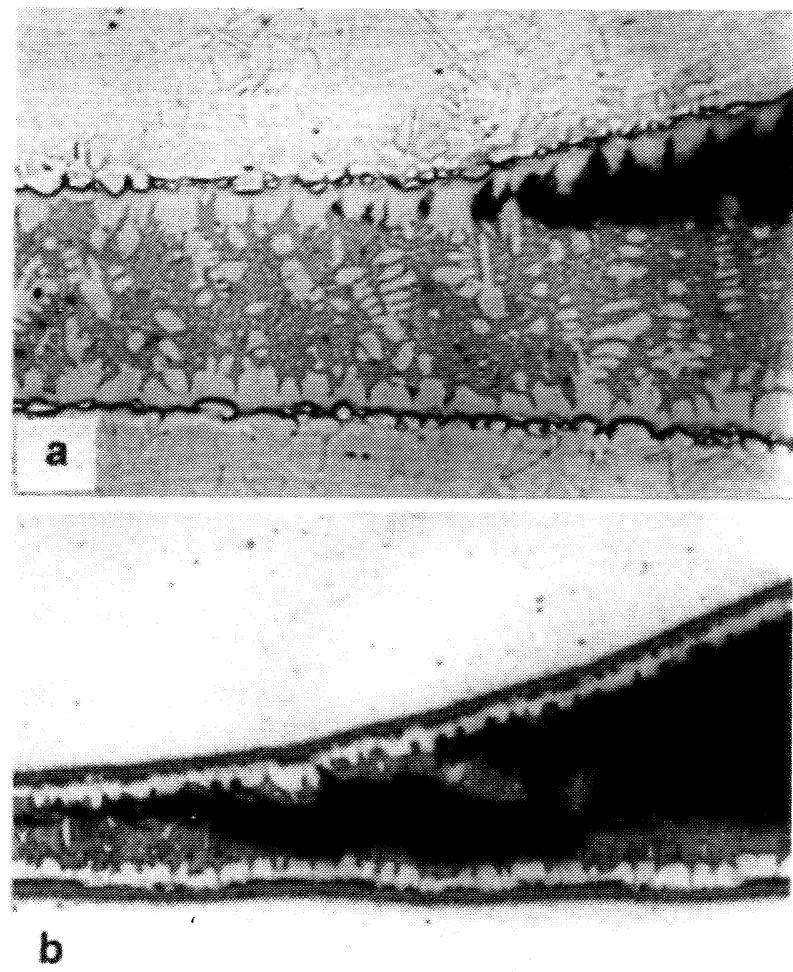

Figura 3. Crack propagation in brittle eutectic in peel test. (a) Brazing alloy: BNi-7; 130x. (b) Brazing alloy: BNi-1; $70 x$.

Figure 3. Expansión de la fisura en la eutéctica frágil durante la prueba de desconchar. (a) aleación: BNi-7; 130. (b) aleación: BNi-1; $x 70$.

That is to say that the primary and eutectic borides in the brazing alloy disappeared due to boron diffusion into the parent metal, where new borides immediately precipitated due to the supersaturation of the parent metal with boron. Annealing of the joint accelerated boron diffusion into the parent metal. When there was only solid solution in the gap, there was no source of boron. The boron concentration in the parent metal close to the gap started lowering due to boron diffusion into the parent metal and back into the solid solution of the joint. Thus the borides started dissolving, and boron passed into the solid solution. With longer annealing times borides would disappear also in the case of a wide brazing gap.

In steel AISI 321 (stabilised with titanium) precipitates may be found in the parent metal close to the gap with $\mathrm{BNi}-7$ brazing alloy (Fig. 4b). They were, however, very few compared to $\mathrm{BNi}-1$ brazing alloy, which is shown in figures $4 \mathrm{~b}$ and $\mathrm{c}$ for gaps of the same width. The precipitates were $(\mathrm{Cr}$, $\mathrm{Fe}, \mathrm{Ti}$ ) phosphides (Fig. 5). It may be observed that titanium strongly bonded into phosphides. 

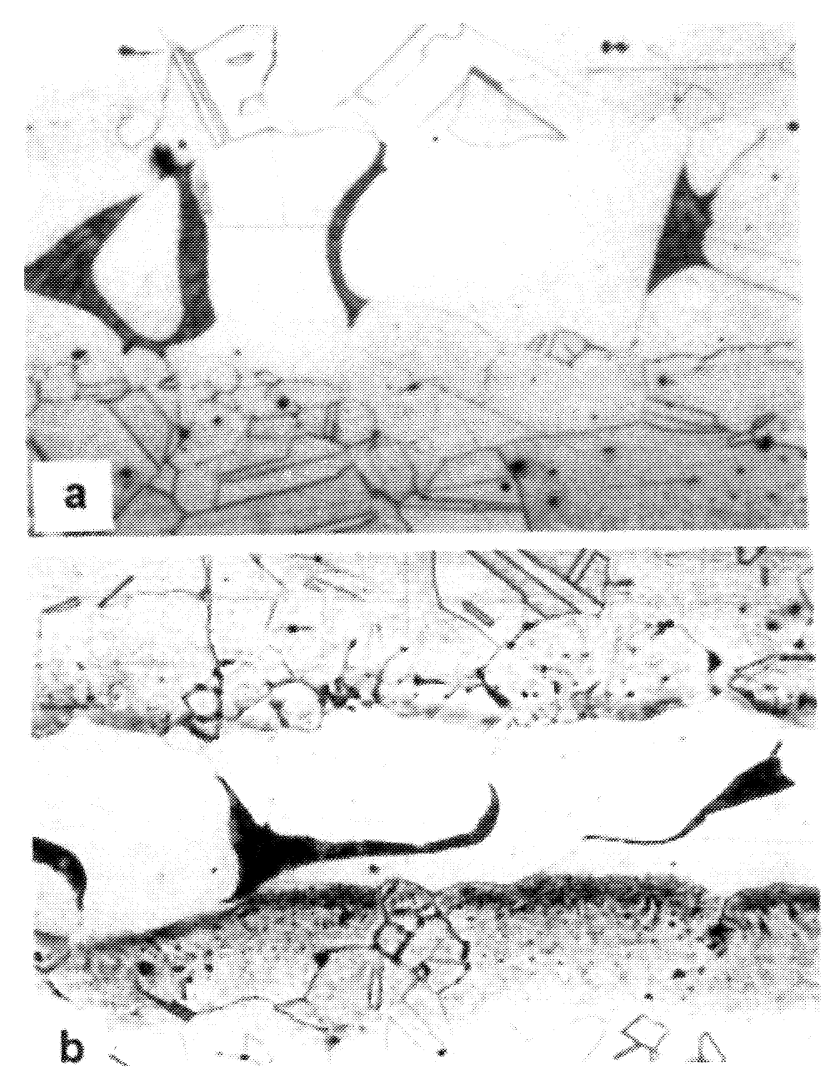

Figura 4. Microstructure of diffusion-annealed brazed joints 130x. (a, b) BNi-7 brazing alloy. (c, d) BNi-1 brazing alloy. (a, c) parent metal: INCOLOY 800. (b, d) parent metal: AISI 321.

Figure 4. Microestructura de uniones soldadas con el recocido de difusión; x130. (a,b) aleación BNi-7. (c,d) aleación BM-1. $(a, c)$ metal de base: INCOLOY $800(b, d)$ metal de base: AISI 321.

Titanium was also in the alloy INCOLOY 800 but there were no precipitates (Fig. 4a). A possible explanation may be a higher content of titanium in steel AISI 321, a hypothesis not studied at this stage. Because of slow phosphorus diffusion into the parent metal, longer times were required for supersaturation of the parent metal; therefore, phosphides precipitated only after longer diffusion annealing of the brazed joints.

The remaining eutectic areas of $\mathrm{BNi}-7$ brazing alloy are important too. In the unannealed brazed joints dendrites of the solid solution are visible at the parent metal in the gap and in the eutectic (Figs. 1a, 3a). In the diffusion-annealed brazed joints there were no dendrites or they were of very small size (Figs. 4a, b). The new solid solution formed grew continuously as a front. This indicated that phosphorus diffusion from the eutectic into the newly formed solid solution was smaller with regard to the parent metal and uniform along the solidus/liquidus interface. This ensures the eutectic concentration of phosphorus in the remaining liquid brazing alloy.

The newly formed solid solution is ductile and the austenitic matrix is precipitation hardened.
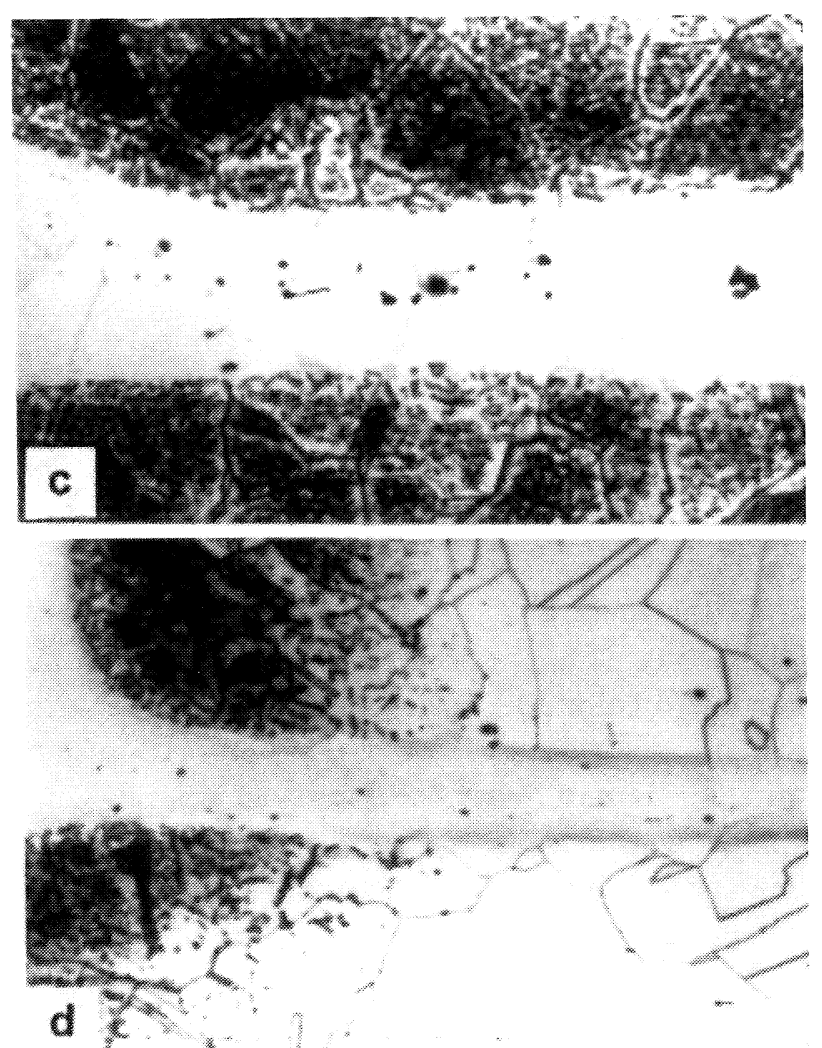

Hardening depends on the distribution and geometry of precipitates. Uniform properties will be obtained after the precipitates have dissolved and disappeared (Fig. 6).

It was found in the bend test that joints made with $\mathrm{BNi}-1$ brazing alloy broke in the zone of the parent metal with a high boride concentration or simultaneously through the boride zone and the solid solution of the gap (Figs. 7a and b). This indicates that borides increased the brittleness of the parent metal and strongly reduced its deformability. Consequently, no joint achieved a bending angle of $180^{\circ}$ without a crack.

With $\mathrm{BNi}-7$ brazing alloy there were no precipitates or they were negligible in number. In the cases when there was no eutectic in the gap, the butt joints achieved the bending angle of $180^{\circ}$, which was the same with the parent metal. Figure $7 \mathrm{c}$ shows that in spite of surface unevenness and a pore, no crack formed.

In another investigation, i.e. on reinforcing of brazed joints ${ }^{[12]}, \mathrm{BNi}-7$ brazing alloy was used in combination with the parent metal, i.e. steel AISI 304, and a reinforcement consisting of parallel wires of steel AISI 304. The reinforcement directly 


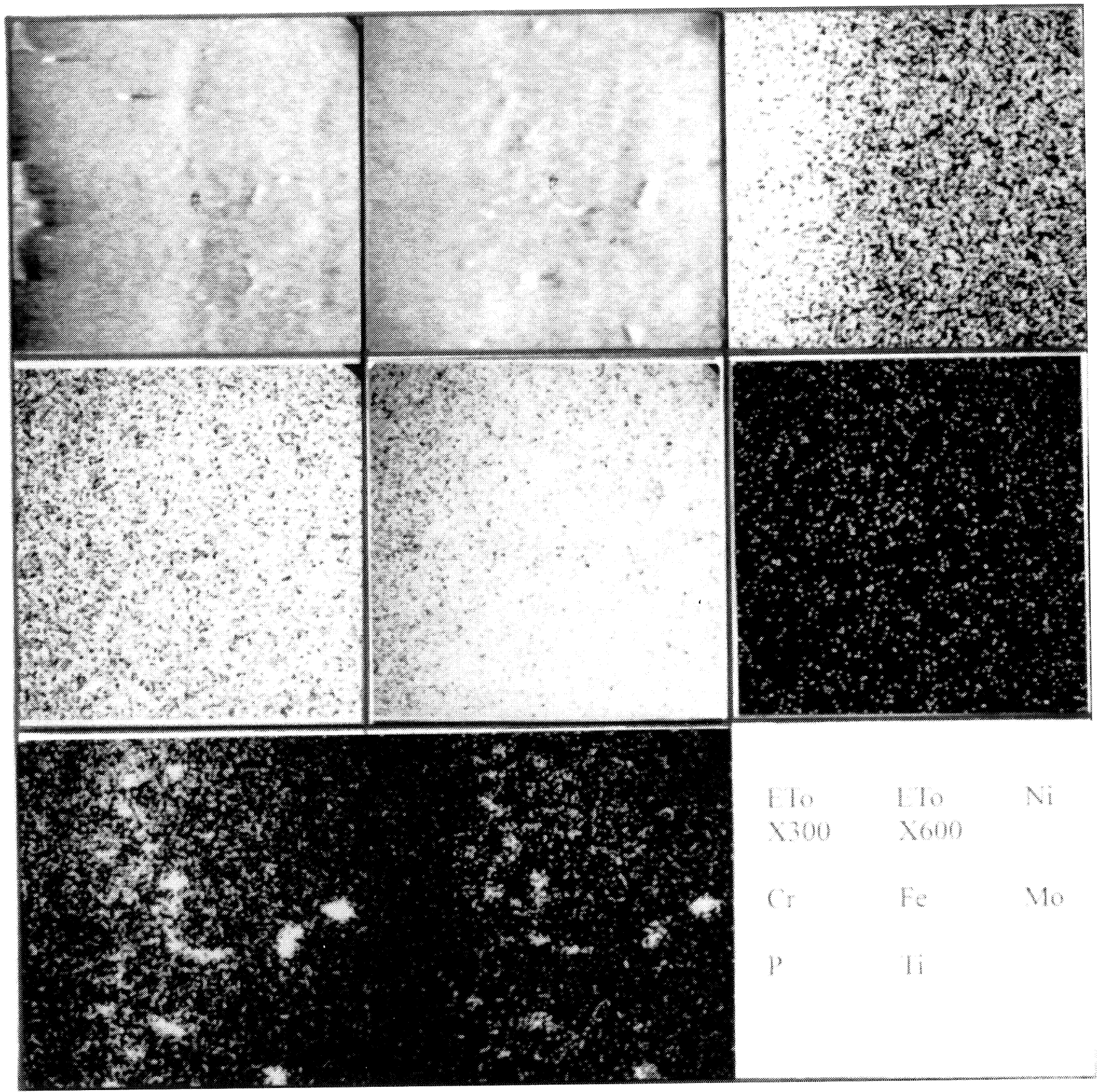

Figura 5. Chemical composition of precipitates in AISI 321 close to the brazing gap after diffusion annealing (BNi-7 brazing alloy).

Figure 5. Composición química de precipitantes en acero AISI 321 al lado de la separación soldada después del recocido de difusión (aleación BNi-7).

coalesced with the solid solution (Fig. 7d, arrow). In the gap there were no precipitates, neither in the parent metal nor in the reinforcement wires. With tensile and impact tests, fracture propagated, through the wires at an angle of $45^{\circ}$, in spite of an unfavourable notch effect at the wire edges and in the remaining eutectic between the wires, but never along the coalescence line between the parent metal and the reinforcement or in the parent metal close to the coalescence line. This was a consequence of the fact that in brazing with
$\mathrm{BNi}-7$ brazing alloy no phosphides were precipitated which would have deteriorated the properties of the parent metal or the reinforcement along the line of coalescence.

\section{CONCLUSIONS}

Our investigations indicate that to achieve a significant improvement of mechanical properties of brazed joints made with nickel-base brazing alloys it is indispensable to transform the eutectic 

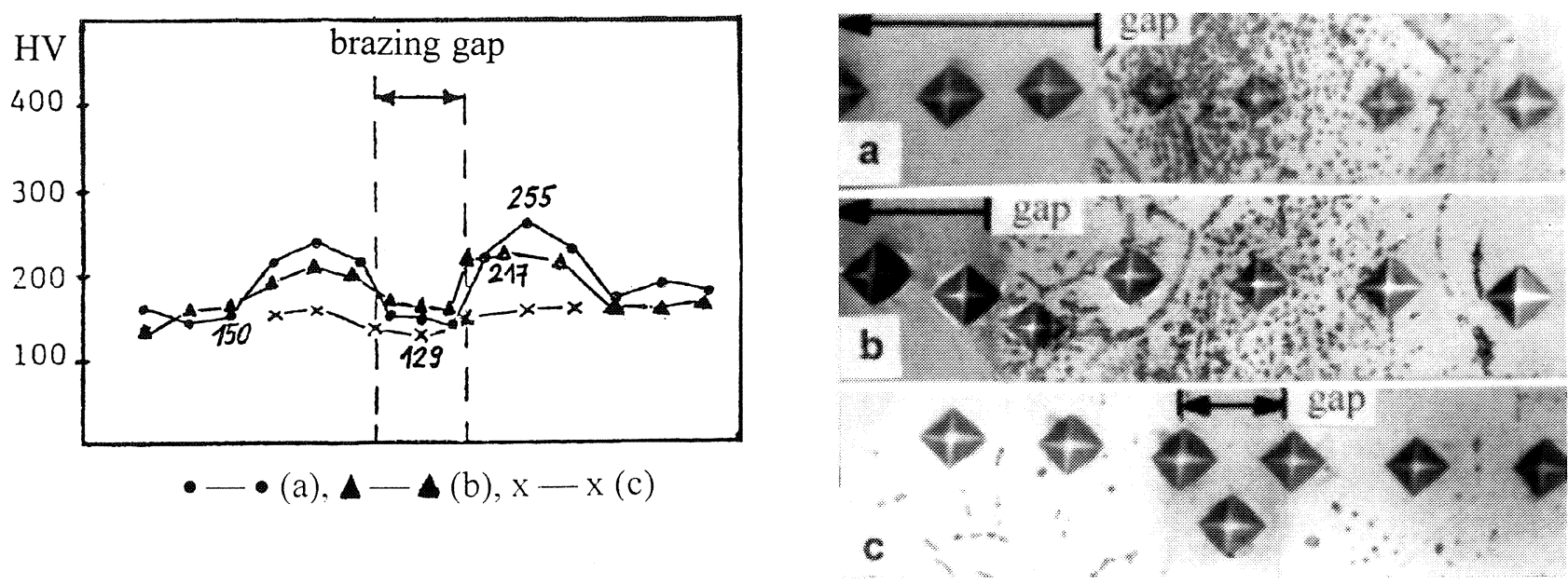

Figura 6. Influence of precipitate distribution on microhardness of diffusion-annealed brazed joint (parent metal: AISI 304, brazing alloy: $\mathrm{BNi}-1$ ); 260x. For an easier examination of the diagram, brazing gaps of equal width were assumed.

Figure 6. Influencia de la distribución de precipitantes sobre la microdureza de la unión soldada con el recocido de difusión (metal de base: acero AISI 304, aleación: BNi-1); x260. Para la explicación más clara, se suponen separaciones soldadas de la misma anchura.
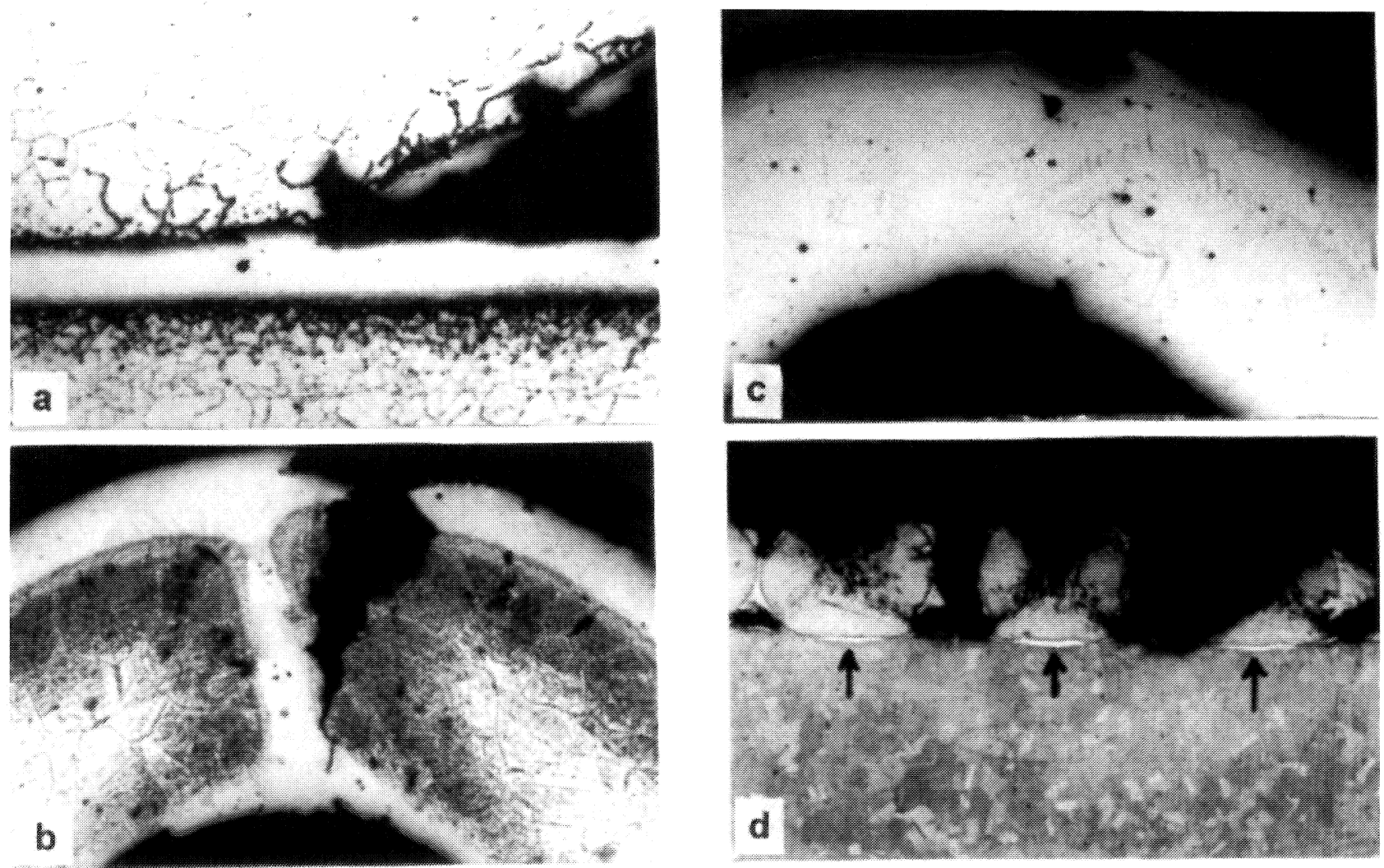

Figura 7. Crack propagation in joints with the single solid solution phase in brazing gap. (a) Parent metal: AISI 321, brazing alloy: BNi-1; 100x. (b) Parent metal: INCOLOY 800, brazing alloy: BNi-1; 50x. (c) Parent metal: INCOLOY 800, brazing alloy: BNi-7; 50x. (d) Parent metal and reinforcement: AISI 304, brazing alloy: BNi-7; 25x.

Figure 7. Expansión de la fisura en uniones de la solución sólida en separación soldada. metal de base: AISI 321, aleación: BNi-1; x 100. (b) metal de base: INCOLOY 800, aleación: BNi-1; x50. (c) metal de base: INCOLOY 800, aleación: BNi-7; x50. (d) metal de base y armadura: AISI 304, aleación: BNi-7; x25. 
into solid solution. In this process brazing alloys containing boron act differently to those containing phosphorus.

In the case of brazing alloys containing boron, i.e. $\mathrm{BNi}-1$, the gap is filled with solid solution, but at the same time the parent metal close to the brazing gap is hardened due to the volume and grain boundary precipitation of borides. The borides produced brittleness and decrease the deformability of this zone. Thus the effect of transforming the eutectic into solid solution was considerable weakening. In order to obtain favourable mechanical properties, it was indispensable to dissolve borides in the parent metal, i.e. to dilute them to a degree where they have no further negative effect.

In the case of brazing alloys containing phosphorus, i.e. $\mathrm{BNi}-7$, the gap is filled with solid solution, generally without precipitation of phosphides in the parent metal. The latter may form in alloys with added titanium, but not necessarily. The phosphide precipitation was most certainly affected by the concentration of titanium, but it may also be affected by other alloying elements which "stabilise" titanium in solid solution. The volume fraction of precipitated phosphides was very small in comparison to that of borides, and the phosphides were thinner. Their influence on the properties of the parent metal close to the gap was negligible in comparison to that of borides.

In the case of brazing alloys containing boron, the eutectic in the brazing gap changed more rapidly into solid solution than with the brazing alloys containing phosphorus, which resulted, in spite of boride precipitation, in an initial significant improvement of the joint properties in comparison to $\mathrm{BNi}-7$ brazing alloy.

A comparison considering the elimination of the brittle eutectic from the brazing gap was, however, inadequate. A belter criterion should consider be a larger area close to the joint where, however, the brazing alloy containing phosphorus, having little or no tendency towards phosphide precipitation, should be given priority. Thus the only suitable comparison of different brazing alloys is the same joint microstructure: solid solution in the brazing gap with no or very few precipitates in the parent metal close to the brazing gap.

\section{REFERENCES}

[1] Brazing Handbook, 4th ed. American Welding Society, Miami, CA, EE.UU., 1991, pp. 65.

[2] E. Lugscheider and K.D.PARTZ, Weld. J. 62 (1983) $160 \mathrm{~s}-1 \cdot 64 \mathrm{~s}$.

[3] H. ZhUANG et al., Weld. World, 24 (1986) 200-208.

[4] G.M. SLAUGHTER et al,. Weld. J. 36 (1957) 217s-225s.

[5] P.P. KING and R.K. MCGEARY, Weld. J. 38 (1959) $241 \mathrm{~s}$ $246 s$.

[6] T. BeLL et al., Weld. Metal Fabr. 44 (1976) 289-293.

[7] R. JOHNSON, Weld. J. 60 (1981) 185s-192s.

[8] Source Book on Brazing and Brazing Technology, ASM, Metals Park, Ohio, EE.UU., 1980, pp. 213-220

[9] E. LUGSChEIDER et al., Weld. J. 59 (1980) 283s-288s.

[10] M. HANSEN and K. ANDERKO, Constitution of Binary Alloys, 2nd ed., McGraw Hill, New York, EE.UU., 1958, pp. 251.

[11] M.C. GarCiA-Alonso et al., Rev. Metal. Madrid, 33 (1997) 250-257.

[12] B. ZORC et al. IIW Doc. IA-1026-98. International Institute of Welding, 1998. 